\title{
What Is Religion in Africa? Relational Dynamics in an Entangled World
}

\author{
Birgit Meyer \\ Department of Philosophy and Religious Studies, Utrecht University, \\ Utrecht, The Netherlands \\ b.meyer@uu.nl
}

\begin{abstract}
Addressing the implications of the introduction of the concept of religion to Africa in the colonial era, this essay approaches religion from a relational angle that takes into account the connections between Africa and Europe. Much can be learned about the complexity and power dynamics of these connections by studying religion not simply in but also from Africa. Referring to historical and current materials from my research in Ghana by way of example, my concern is to show how a focus on religion can serve as a productive entry point into the longstanding relational dynamics through which Africa and Europe are entangled. This is a necessary step in decolonizing scholarly knowledge production about religion in Africa, and in religious studies at large.
\end{abstract}

\section{Keywords}

translation - 'incurably religious'? - materiality - relationality - entanglement

\section{Introduction}

Sixty years after many countries in sub-Saharan Africa gained independence from European colonialism, there is still an urgent need to acknowledge and identify the resilience of what Valentine Mudimbe aptly calls 'epistemological ethnocentrism' $(1988,28)$. This also plays out in the study of religion-in Africa and beyond. His book Invention of Africa appeared more than thirty years ago, but even though the need to 'provincialize Europe' (Chakrabarty 2001) is often emphasized in academic knowledge production about other parts of the world, 
much thinking about how exactly to decolonize our approaches, concepts, and curricula is still to be done. As a scholar born and living in Europe who has been conducting research on religion in Ghana for more than 30 years, I opt for a relational approach that takes into account the past and present connections between Africa and Europe. Rather than seeking to reimagine Africa in indigenous terms, as advocated by some Afrocentric thinkers, I take a transregional perspective on past and present African-European entanglements, and their repercussions for the production of knowledge in the past, the present, and for the future (Meyer 2020a, see also Meyer 2018). I use the term 'entanglement' to refer to a hyperconnectivity in which historically constituted relations between Africa and Europe - and other regions-intersect and criss-cross each other on many levels, making it impossible to take a sharp distinction between these regions as an imagined starting point. Entanglement cannot be reduced to straightforward relations between A and B, but involves a complex, dynamic formation that scholars are to unpack.

This perspective is inspired by the point made persistently by Achille Mbembe to understand Africa as inextricably connected with the world. Speaking from Africa, he states:

It is not simply the case that a part of African history lies somewhere else, outside Africa. It is also that a history of the rest of the world, of which we are inevitably the actors and guardians, is present on the continent. Our way of belonging to the world, of being in the world and inhabiting it, has always been marked by, if not cultural mixing, then at least the interweaving of worlds, in a slow and sometimes incoherent dance with forms and signs which we have not been able to choose freely, but which we have succeeded, as best we can, in domesticating and putting at our disposal. $(2007,26)$.

Taking this insight to heart has repercussions for how we, Western and African scholars, conceive of the study of religion in Africa. 'Africa is not what it is because of what it is like. Africa is what it is because of what the world is like, and vice versa. So we study Africa to understand the world', as Elísio Macamo $(2018,8)$ puts it aptly. The idea of studying Africa to understand the world in ways that transcend a still-lingering Eurocentrism, yet also an Afrocentrism that speaks back to criticize this position, ${ }^{1}$ also drives my own scholarship. Against this backdrop I do not regard the study of religion in Africa as being merely about Africa; in fact, I wonder ever more what 'religion' 'in' 'Africa' actually is. The expression 'religion in Africa' normalizes what should be questioned: what do we mean by it? How far does the study of religion in Africa always 
already presuppose a perspective from Europe? How can we develop the study of religion in Africa in a critical and productive manner that does not confine it to a regional subfield that scholars in the study of religion outside of African studies can comfortably neglect? How do we open up vistas 'to understand the world' from the angle of interwovenness, in the sense of Elísio Macamo and Achille Mbembe, through studying religion from Africa?

Obviously such big questions cannot be answered in one essay and require extensive discussion among scholars. They are prompted by my research among the Ewe in Ghana, which often left me wondering how to convey my findings in scholarly discourses about religion. This puzzlement was enhanced with my move from cultural anthropology to religious studies in 2011, which involved the need to familiarize myself with a more generalizing discourse about religion, in the light of which my work on religion in Africa somehow seemed to be peripheral. My main concern here is to explain, in the light of my research, why it is important to pose these questions and, in so doing, to spotlight some crucial issues that are to be addressed in order to deconstruct the epistemological ethnocentrism that Mudimbe has already diagnosed. As Eva Spies puts it poignantly: 'Epistemologies are not givens but decisions on how knowledge should be produced. To rethink them is one step in the endless loops between social exchanges through research, the realities they generate, and their theorization' $(2019,63)$. Africa, Europe, and religion are epistemic objects that, rather than being 'found' in the world out there, always already determine how we study that world (see also Zobel 2011). The challenge is to denaturalize these epistemic objects and critically assess how they inform knowledge production about the world without breaking up their historical connectedness. In my view, the aim is neither to return to an idea of Africa as situated outside of the sphere of Europe (and vice versa) nor to abandon the term 'religion'. The concept of religion is to be opened up from the relational dynamics across them.

\section{$2 \quad$ Studying Religion in Africa}

The study of religion in Africa is a thriving field with researchers from Europe, Africa, and elsewhere. In its history of more than fifty years, the Journal of Religion in Africa has been a stimulating forum to assemble this scholarship and offer a platform for critical debates. It offers articles based on grounded historical and ethnographic research about a plethora of themes, with Christianity and so-called ATR (African Traditional Religion) being the prime focus, next 
to Islam and, more recently, religions from Asia. While this regional expertise is tremendously important, it also has certain limitations. Once one is inside this field the focus on religion in Africa and the ways of studying it may easily be taken for granted. However, since religion in Africa is not simply about or confined to Africa, its study must be situated in a broader frame than that of African studies, extending at the very least into the broader discipline of religious studies in which region-specific expertise still tends to be marginalized, despite persistent calls for reconfiguration and decolonization (Klinken 2020; Nye 2019).

Notwithstanding the existence of the African Association for the Study of Religions (ASSR) and sections focusing on African religion and religions within the American Academy of Religion (AAR) and similar institutions, religious studies and the study of religion in Africa are not yet as integrated and synergized as one might wish. Usually the study of religion in Africa remains one regional subfield among others that scholars interested in religious studiesconceived as a generally applicable set of theories and methods with regard to comparative religion - think they can afford to neglect. With this essay I would like to assert and explain why this stance is problematic. It forms the counterpart to my essay 'Remapping our Mindset' (2020a), in which I argue that there is need for a reorientation of religious studies - and of academia in generalthat takes fully into account the transregional connections between the former European centres of knowledge production and areas of imperial European outreach so as to develop fresh postcolonial perspectives for the study of religion in our entangled world. The point is that region-specific knowledge (also beyond Africa) is usually much more sensitive to historical transregional entanglements than knowledge produced from the presumed centre with its abstract universalizing claims. Hence such knowledge from and about Africa must be engaged outside of the confines of African studies, so as to 'provincialize' central analytical concepts and build a new, non-Eurocentric conceptual framework for the study of religion.

In this part of my essay I concentrate on the epistemological implications of the introduction of the term 'religion' into Africa. The key question here is how religion, as a term denoting a concept, got to Africa and how its introduction (mis)represented, yet also affected, the African ideas and practices to which scholars, missionaries, and colonial administrators made it refer. My point is not that what is referred to as religion in Africa should not be designated by that term and be replaced by indigenous alternatives. On the contrary, it is exactly by focusing on the use of 'religion' - taken as an umbrella term that encompasses a broader vocabulary — that it is possible to gain a sense of how 
'Africa' is part of religious studies, and of how Africa and Europe are inextricably intertwined, even though this is ill recognized or, at least from a European mainstream perspective, conveniently 'forgotten' (Fabian 2009). Here the work of David Chidester, who called to resituate 'comparative religion in the historical context of colonial conflict' (1996, 1), offers a productive starting point. As he points out in his book Savage Systems, the human sciences, including comparative religion and anthropology, 'in their constitution as authoritative and eventually, professional knowledge, disguised their origin in this reality of intercultural contact and exchange, even preventing any recognition that their foundational notion of the human depended upon the new interchanges of an expanding global order' $(1996,1)$. Chidester traces the emergence of comparative religion back to the frontier zones of European colonial outreach in which intruders and indigenous people assessed, constituted, and contested the concept of religion and related terms under unequal power relations. ${ }^{2}$ As he puts it ironically and succinctly: 'Before coming under colonial subjugation, Africans had no religion. After local control was established, however, they were found to have had a religious system after all' $(1996,20)$. Taken to offer evidence for a low stage in the evolution of religion, this African religious system was relevant for the comparative study of religion emerging in the mid-nineteenth century. Chidester's critical epistemological project of tracing back the terms employed in the study of religion from the European centres to the colonial frontier zones is an important step in assessing the conceptual repercussions of knowledge production about religion under imperial conditions that still haunt the production of knowledge in religious studies (see also Chidester 2014). Clearly, studying religion in Africa is not confined to a conceptual space 'within' Africa, but enshrines a long history of African-European economic, social, political, and conceptual connections under unequal power relations that must be scrutinized and unpacked.

I agree with Chidester that by tracing the history of such entanglements to the frontier zones in which European-African relations were shaped, 'it is possible that we might clear a space-perhaps even a postcolonial, postimperial, postapartheid space-where something new in the study of religion might happen' (1996, 266; see Meyer 2018, 61-62). This wish for something new to happen underpins my question 'What is religion in Africa?' In my view it can only be answered satisfactorily by gaining a sound historical consciousness of the relational dynamics through which Africa and Europe became, and still are, entangled. In so doing, I want to address two critical issues that underpin the study of religion in Africa-the difficulty of translation and Africa's presumed religiosity, in the sense of an existential, deeply felt orientation toward the divine. 


\subsection{Translation}

"How to analyse "religion" in a society in which the concept of "religion" is absent?' Louis Brenner $(1989,87)$ asks poignantly. External European concepts define what is meant by 'religion in Africa'. This involves the use of a Christian concept of religion that emphasizes belief, knowledge, and churchlike community, at the expense of the dimension of people's participation in 'religious' rituals and the ritualized embodiment of knowledge. His critique resonates with the point made by such scholars as Talal Asad (1993), that the academic study of religion is indebted to post-Enlightenment, Protestant, and by now secularized notions of religion that are mistaken as universal, and thus tend to misrepresent Islam as well as indigenous traditions. Still, Brenner is not advocating abandoning the use of the term 'religion'; putting it in quotation marks, he wishes 'to encourage a more open and questioning attitude of what might constitute "religion" in African societies' (Asad 1993, 102), especially by acknowledging the importance of music, dance, and the body. I agree with Brenner's point that a critical focus on translation yields important insights about how the term 'religion' touched ground in Africa.

For instance, my research on the activities of nineteenth- and early twentieth-century German missionaries in what is present-day Ghana and Togo (1999) showed that they represented the Ewe, among whom they conducted their proselytizing activities and ethnographic research for the sake of conversion and scholarship, from a Protestant viewpoint. In his ethnographic work Die Religion der Eweer in Süd-Togo (1911), the missionary Jacob Spieth typically started with the belief in a distant high God_-Mawu — from whom the Ewe had become alienated, and then moved to the many indigenous and foreign gods (trõwo), religious secret organizations (Yewe), the belief in the soul, to sorcery $(d z o)$, divination $(a k a)$, and witchcraft (adze). Relying on translated statements of Ewe informants whose identity he did not disclose, the book is a highly valuable resource. ${ }^{3}$ However, in opting for an order from high to low and from indigenous to foreign, Spieth presented a normative, theological view of actual Ewe religion as degenerated from its initial core and purity. This view resonated with a typical Protestant missionary view of African peoples having lost their link with a high God, a link that was to be remade through conversion to Christianity (for a critical analysis of the attribution of Western and Christian features to Mawu see Greene 1996). It also privileged an idea of ethnic identity that was understood as pure and authentic, and as challenged through encounters with other ethnic groups as well as European influences; this problem of loss of purity was, again, to be remedied through conversion, with the mission assuming a key role in the formation of a Christian Ewe nation (Meyer 2003). Such Christian views became inextricably connected with and 
lingered on in ethnographic descriptions; they are difficult to spot and get rid of, as I also noticed in my research.

As noted, the possibility of detecting the misrepresentation of African ideas and practices that occurred by describing them through a European missionary lens that shaped ethnographic descriptions depends on tracing the work of translation, through which certain associations and analogies were construed (see also Horton 1984, Shaw 1990). In Ewe, for example, the term that came closest to religion was subj̃subj, which could better be translated as 'worshipping' or 'serving. These terms emphasize practices, whereas the missionaries' notion of religion foregrounded cosmologies and beliefs. For them, Mawu was the lost God the Ewe were longing to be fully reconnected with, and Sasabonsam, the bush-monster, became the devil who presided over the trõwo whom the Ewe falsely worshipped and the charms (dzokawo) they used for protection and inflicting harm on enemies. These were powerful missionary translations that drew Ewe terms not only into a Christian vocabulary and made it compatible with Christianity, but also into a narrative of degeneration and possible redemption through conversion that was broadly shared in Protestant mission circles (Warneck 2015[1897]). Such a 'theological reductionism' is due, as Emefie Ikenga-Metuh pointed out long ago, to a 'failure to realize that the differences in the beliefs of different cultures are at least as important as their similarities in an interpretation' $(1982,14)$.

For scholars studying religion in Africa, such translations and the views they transport cannot be taken for granted, yet they persist despite longstanding critiques of 'theological reductionism,' especially in the context of debates about African notions of a high God (Greene 1996; Horton 1975a, 1975b, 1984; Ikenga-Methu 1982; P'Bitek 2011; Shaw 1990, 343-345). The point is that such translations yielded misrepresentations that became ossified and still linger on in how Africa is represented, also on the part of Africans (see below). From a critical anthropological angle (Asad 1986; Hanks and Severi 2014), the aim of translation is not to submit foreign terms to Western ones, thereby smoothing out differences, but to engage with differences. Translating and studying translation in this manner makes it possible to discern the coexistence of the known and the foreign in specific power relations. Since 'translation in the colonial setting produces the objects of our historical knowledge' (Hanks and Severi 2014,7 ), scholars of religion must pay utmost attention to how their scholarly discourse mediates missionary translations of indigenous views, and negotiate whether to employ existing translations or suggest new ones. Translation being a key feature of colonial encounters and the entanglements that ensue from them, it is a crucial task for scholarship to reflect on the language employed to convey knowledge about religion in Africa. An open-minded translation of 
religion and associated terms, and the critical tracing of past translations can spotlight alternative possibilities and break open the concept of religion as narrowly understood from a European, Christian angle.

Speaking about religion in Africa thus requires, to invoke Dipesh Chakrabarty (2001), the preparedness to 'provincialize' a European take on religion in the light of alternative human-spirits relations. As Michael Lambek argues,

to provincialize God is to draw on European thought and yet at the same time to try to step outside the Abrahamic traditions to recognize how it has influenced secular thought about religion ... and to try to imagine how something like 'religion' ... might look outside the Christian and Islamic spheres. $(2008,121)$

He substantiates his point by turning to the Nuer religion, as documented by Evans Pritchard (1956). Lambek argues that translating the Nuer term Kwoth as God was problematic because this translation failed to capture the specific, deictic manner in which Kwoth was spoken about among the Nuer: not as an objectified God out there, but in an indexical manner that signals the presence of $K$ woth in relation to the speaker mentioning his name.

For scholars translation involves not only a search for roughly equivalent terms for God, the devil, or the Holy Spirit in vernacular vocabularies and vice versa, as I realized through my research. Even more complicated, as Lambek shows, is the problem of conveying equivalent semiotic relations between humans and spirits as they are mobilized in modes of speaking. Taking a 'provincializing' stance toward the translation of Western terms with regard to religion and related terms into African languages and vice versa recognizes that it would not be possible to engage in conversations about such human-spirits relations without these terms, and yet acknowledges that they are incommensurate and inadequate. In order to decolonize the study of religion in Africa, as scholars we should be much more aware of the extent to which our object of research and the language we employ is conditioned by translation in that a hitherto foreign set of terms under the umbrella of 'religion' was introduced to describe, value, and govern specific forms of human-spirits relations in Africa. ${ }^{4}$ To retrieve and reconsider what was lost in and yet created through translation is all the more important since the concept of religion was part of colonial policy in regulating — and at times policing — ways of engaging with the spirit world, and also has become part of postindependence state policies (see Meinema 2021). As a concept translated from Europe to Africa, religion was pluralized in administrative policies, scholarly discourse, and public debate, producing essentialized distinctions between Christianity, Islam, and what 
was reconfigured as African Traditional Religion (ATR). ATR itself is a concept that emerged through a highly problematic generalization (Shaw 1990), and movements claiming this term often adopt a Christian form that is to be filled with traditional content (de Witte 2004). Mapped on yet brushing over previously existing semantic networks, categories, and hierarchies, the distinctions between such 'world religions' as Christianity, Islam, and ATR also shape the study of religion in Africa. This yielded a bifurcated field of scholarship on Christianity on the one hand, and Islam on the other, at the expense of research on modalities of religious coexistence in the past and present (Janson and Meyer 2016; Janson 2021; Nolte, Ogen, and Jones 2017). Older relations, mutual influences, and views about each other, especially between Islam and indigenous traditions (Pontzen 2019), got out of view.

\subsection{Africa's Presumed Religiosity}

Notwithstanding the constraints posed by translation, the term 'religion' was successfully introduced across Africa. By now Africa often features as a privileged site for the study of religion, and of Christianity in particular. Despite the fact that the term 'religion' was of European origin, the idea of Africans as being profoundly_-'notoriously' (Mbiti 1969, 1) or even 'incurably' (Parrinder 1969, 235) - religious was also embraced by African scholars of religion, many of them situated in the ambit of liberal Christian theology. Asserting the deep religiosity of Africans and tracing it back to their traditional religiosity, the work of such scholars as John Mbiti resonated with the search for a panAfrican personality launched by Kwame Nkrumah and Senghor's project of Négritude in the 1950s and 196os. The assertion that Africans are, above all, deeply religious beings was initially made as a critical pan-African response to the repercussions of earlier denials of religiosity in regard to Africans in the seventeenth and eighteenth centuries, and their characterization as being exponents of 'primitive' and 'bad' religion - 'idolatry', 'fetishism', 'paganism'with the onset of colonization and missionization in the nineteenth century (Chitando 1997; Platvoet and van Rinsum 2003).

Assertions of an essential Africanness rooted in religion may be a resource for pride and self-esteem, but also has certain problematic consequences (for an early critique of the 'devout' stance taken by such scholars as Mbiti and Turner see Horton 1984). It is one pole of a false ideological binary that opposes a view of Africa as religious to a view of Europe as secular, echoing the well-trodden contrast of a presumed African emotionality with a European rationality. In the current global configuration, Europe has indeed gone through a process of remarkable dechurching, with the Netherlands, where I live, at the vanguard. There on average one church is closed down per week, and religion tends to 
be taken as a matter of the past and valuable as heritage, while in its living form it is often seen as a nuisance (Meyer 2019). At the same time, a characterization of Europe as secularizing, in the sense of the eventual disappearance of religion, is wrong; religion continues to thrive in many forms, even as a 'secular sacred' (Balkenhol, Hemel, and Stengs 2020). Nonetheless, in line with mainstream public discourse, for many people in Northern Europe religion connotes backwardness - especially Islam, but also Evangelical Christianity. Against this backdrop the characterization of Africans as being 'notoriously religious' transports, once again, a temporalizing idea of Africa as not yet secular and rational. ${ }^{5}$ In the light of the earlier view of Africans as not having religion, the irony of this characterization cannot be missed. By the same token, for some Christians in Europe and the United States Africa is made to stand for the future and hope of Christendom, supported by the recent statistics provided by the Pew Research Centre (2015). Also, it is regarded as the place from which a 'reverse mission' (e.g., Adogame 2013) is unleashed to re-evangelize Europe which many African Christians see as morally defunct.

My point is not to deny the existence of these views and activities, but to deconstruct the naturalization of Africans as religious, as well as the takenfor-granted manner in which 'religious' is often understood from a European angle. Here I echo the point made by the religious studies scholar Eze Chitando more than twenty years ago:

One may sympathise with their (Mbiti cum suis, BM) cultural nationalism, but celebrating African religiosity is no substitute for a critical examination of what the term 'religion' implies in an African context. To speak of religion in the manner that they do is to extirpate the very concept they seek to clarify. $(1997,90)$

In their much-debated article Is Africa Incurably Religious? (2003), Jan Platvoet and Henk van Rinsum point out that the ontologization of Africa as religious purports a problematic 'mythic dichotomy of religious Africa versus secular Europe' $(2003,8)$ that affirms a false opposition of 'us' and 'them' mapped on the religious-secular distinction. ${ }^{6}$ Such a stance continues to produce Africa as Europe's eternal Other, with the religion-secular binary serving as the ground for their separation. An idea of Africa as deeply religious, 'still enchanted' (Taylor 2007, 11), or as 'never-secular' (Luhrmann 2012) is wrong not only because it lacks empirical evidence, but also because it denies Africa coevalness (Fabian 1983) with secular Europe, thereby affirming longstanding exoticizing stereotypes with regard to Africa and an idea of European supremacy vested in secularity. Maintaining this idea is doubly problematic. It not only 
unquestionably transports to Africa a Western, Christian understanding of religion in terms of belief, but even attributes religion with a persistent and encompassing influence on all facets of life. This neglects the fact that traditionally differentiations were made between what in retrospect one could call 'religious' and 'secular', or 'sacred' and 'profane' (Chitando 1997, 91), as well as that modern states in Africa actually do have secular constitutions and relate to religion in a secular framework (Engelke 2015). The characterization of Africans as religious by nature stands in the way of exploring the implications of the introduction of the concept of religion — and on its flip side that of the secular-into Africa for scholarship, governance, and everyday life.

To conclude this part, the point is that a casual use of the expression 'religion' in Africa can easily make us brush over the fact that religion was introduced to Africa as a concept from Europe. It was made operational in colonial rule, missionary activities, and scholarship, and in the process was appropriated by African converts to Christianity, so-called traditionalists as well as policy makers and scholars, and eventually even adopted as a key characteristic of Africans by Mbiti and others. ${ }^{7}$ Spotlighting European colonial influences and their appropriation in the study of religion in Africa so as to create awareness for the biases and histories of scholarly concepts is an important step in developing a decolonial perspective on global religious history and in grasping global entanglements. Having problematized translation and cautioned against a naturalizing characterization of Africans as religious, I opt to approach the study of religion in Africa as an open project through which we can extend our understanding of religion by studying it from Africa.

\section{$3 \quad$ Studying Religion from Africa}

What then could studying religion from Africa mean? Back in the 1970s Ugandan scholar Okot P'Bitek stated that there is need to get rid of 'the very disparaging assertions of Western scholars about African religious conceptions' (2011, 33). His powerful book points out that African scholars who sought to move beyond colonial and missionary accounts of religion were trapped in Western, Christian modes of analysing religion in Africa, failing to describe African religions in their own terms (see also Horton 1984, 391-392 for an appraisal). This failure, of course, is due to the fact that what was framed as religion in Africa was not confined to a separate domain in society, but was grounded in entirely different conceptions than those prevailing in theological—and scholarlyapproaches to religion in mentalistic terms. 
For P'Bitek, studying African religions in their own right could only be achieved through a decolonizing move that critically traces the history of the study of African religions in Western scholarship, and seeks to develop alternative insights. For him this meant getting out of the trap of speaking back in colonial, missionary terms. He urged African scholars to do this so as to develop a more truthful picture of religion in Africa. 'Disentangling', as Ghanaian philosopher Kwasi Wiredu put it in the essay that precedes a reprint of P'Bitek's book, 'African frameworks of thought from colonial impositions, is an urgent task facing African thinkers at this historical juncture' (2011, xxxvii). For him this is the condition for rethinking the universal from the bottom up, rather than from the top down in the usual Eurocentric manner.

The study of religion is to be decolonized not only in African studies but also in academia at large, and in this regard Western scholars also have a responsibility to rethink their approaches and remap their mindset. As pointed out in the beginning, in my view the aim is not a turn to an indigenous Africa, imagined as stripped of Western ideas and influences. Even if this would be possible, it would not be an option I could take as a scholar trained in Germany and the Netherlands. Taking as a starting point the entanglement of Africa and Europe under highly asymmetrical conditions, I seek to develop a symmetric anthropology (Latour 2010). This means that one has to work through subsequent layers of translation and (mis)representation as they occurred in historical encounters that critical scholarship is to unpack through a detailed analysis of sources. Proposing to study religion 'from' rather than simply 'in' Africa, I want to signal the importance of taking an alternative vantage point for the study of religion, rather than it-implicitly—being studied 'from' Europe. The point here is to view Europe not simply in geographical terms, but to deconstruct it as the claimed centre for the production of knowledge about the world in the name of the universal (Mbembe 2017). Even though colonialism has passed, the way in which scholars produce knowledge about religion still bears traces of the very same Eurocentric and Christian bias signalled by P'Bitek and Wiredu.

The expression studying religion from Africa resonates with the "Theory from the South' project launched by Jean and John Comaroff. Thinking theory from the South, from Africa, does not aim to affirm the North-South binary, but is to 'lay bare the larger dialectical processes that have produced and sustained it' (2011, 2). Studying religion from Africa, I would say with the Comaroffs, 'invites us to see familiar things in different ways' $(2011,2)$. This project also resonates with Mbembe's proposal to think (about) the world from Africa. Doing so does not increase the distance between Africa and Europe, as well as other 
parts of the world, but decentres relations of power so as to create the possibility of a new universality beyond the Eurocentrism of the Enlightenment (2017), according to which Africa was deemed unable to bring forth the universal and doomed to remain particular and deviant: a dark world apart epitomized by the racist figure of the 'Negro' (Mbeme 2014, 100-101). ${ }^{8}$

So how does taking Africa as a vantage point allow scholars of religion to see a presumably familiar thing as 'religion' in different ways? Posing this question, my concern is to help reconfigure religion as an open concept 'through which certain practices, ideas and things-e.g., with regard to the mediation of a sense of a "beyond" - can be grouped and compared' (Meyer 2020b, 3). It is a concept that is not yet fixed and filled, but still to be developed through research 'from' Africa (and 'from' other places in the Global South). There are many important themes; in the following I want to highlight two: being in the world, and relationality.

\subsection{Being in the World}

P'Bitek states:

African religions are not so much concerned about the beginning and end of the world, they are rather more concerned with the good life here and now, with health and prosperity, with success in life, happy and productive marriage, etc.; they deal with the causes of diseases, with failures and other obstacles in the path of self-realization and fulfillment. $(2011,30)$

The point here is not to make an essentialized statement about what 'African religions' really are, but to counter the ideology that underpins their misrepresentation. This misrepresentation was due to the fact that they have been described from a Western, Christian mindset that was geared to an ontological difference between transcendent and immanent, spiritual and material, belief and reason. For this very reason Wiredu even suggests that the engagements of Africans with superhuman spirits should not be termed religion at all. However, as proposed, I think that we can also take notice of such engagements to think about religion otherwise.

In my recent work I have sought to contribute to developing a material approach to religion (Meyer 2012). The aim of this approach is not to reduce religion to sheer materiality, but to recapture a crucial dimension of religion that has been sidelined by its Protestantization and dematerialization (see also Bräunlein 2016, 370-373). ${ }^{9}$ Such a dematerialized, mentalistic understanding 
of religion served as the yardstick to classify and hierarchize other religions across the world. Africa was taken to be an abode of 'idols' and 'fetishes' by missionaries, and a prime site of primitive religiosity by scholars. By critically analyzing the ideological use of such a notion of religion its limits become evident, and by turning to Africa possibilities open up to see religion in a different light.

In my research work on the operations of the Norddeutsche Missionsgesellschaft (often referred to as Bremen Mission) among the Ewe, I noted that the missionaries were not only preaching against so-called heathendom and idolatry, but also purported a new mentality and possibilities for participation as producers, traders, and consumers in the modern colonial economy. In this sense the mission was quite worldly and mundane even though the missionaries themselves did not like to acknowledge this in full, and rather lamented about the materialism and lack of spirituality of their converts (Meyer 1997). Above all, the missionaries' descriptions of their endeavors laid bare their own concerns and contradictions, which arose from promoting conversion in a new colonial world of so-called legitimate trade that succeeded centuries of slave trade. When reading missionary texts-including propaganda for the mission as well as internal reports and ethnography - from a critical angle, Ewe interlocutors appear to be very reasonable and calculating persons, both in their religious practices and their mundane activities. In fact, it would even be artificial to separate these. There are spirits in relation to all domains of life, but they are not understood as immaterial gods: they become material in certain places and through certain things at certain times, while at the same time these places and things are not always approached as being or hosting spirits (Adjei 2019; see also Platvoet 2004 with regard to Akan stances towards spirits).

Rather than seeing this link between spirits and matter as an expression of 'animism' or 'fetishism', it makes much more sense to acknowledge that from an Ewe or Akan view-point spirits are 'a regular part of the resources of the world' (Wiredu 2011, xxvii). Indeed, 'if human beings understand how these powers function and are able to establish satisfactory relations with them, humans can exploit their powers to their advantage' (ibid.). This insight, which is broadly shared across Africa and beyond, certainly undermines conventional views of Africans as being deeply religious in the usual sense of devout belief and community worship. It is rather a grounded, embedded, and to some extent instrumental and quite individualistic religiosity that is not separate from what we call economy but inflected with it, in that spirits themselves are understood as even human-made (Barber 1981) resources that feature in the allocation of other resources (see also Mbembe 2017, 193). This implies that what is referred 
to as 'religion in Africa' should not be narrowed down to the sphere of belief as conventionally conceived, but be understood as a mobilization of spiritual resources for all sorts of human projects.

As Hermen Kroesbergen points out in a recent article (2019), European missionaries and scholars failed to recognize these attitudes toward spirits as religion because they were confined to a European concept of religion that took belief and community as key elements.

Interestingly, according to Kroesbergen Pentecostalism, which is often criticized as being a foreign Christian movement that is against African culture and religion, brings back 'an African concept of religion without worship groups defined by an adherence to a particular picture of the world' $(2019,1)$. Indeed, notwithstanding the sharp criticisms Pentecostals have with regard to indigenous African traditions, they share with the proponents of these traditions a strong worldly orientation (see also de Witte 2008). Across Pentecostal churches the Holy Spirit is mobilized as a resource that allows the achievement of spiritual resources in a highly competitive world in which health and well-being are under siege, and people feel anxious and insecure. The point here is that rather than express some kind of puzzlement about religion in Africa being world oriented and materially grounded, it is important to think about these orientations as a normal dimension of religion that has been sidelined and devalued due to the proverbial Protestant bias that has had strong repercussions on knowledge production about religion. In this sense, research on religion in and from Africa can correct a narrow, Eurocentric conceptualization of religion that, though subject to critique, still lingers on in religious studies.

\subsection{Relationality}

While conducting research among the Ewe and working through missionary materials, I have always been struck by the strong idea of persons being connected with other persons and spirits. This shows a sociality of relations in which people derive their identity through connections. Connections can also be a source of trouble and mishap, as is the case with witchcraft since witches are understood to have access to a person through blood ties and other intimate links (see also Geschiere 1998; Richter, Flowers, and Bongmba 2017). Connections with spirits may also come about by receiving certain objects (gifts as well as commodities), consuming food, or having sex.

In indigenous Ewe religiosity much emphasis is placed in practices of binding, for good and bad. In Pentecostal deliverance sessions during which people come with certain afflictions, I often heard that people felt invaded by forces from outside, which they experienced as harmful. During my research pastors talked about the importance of cutting blood ties through deliverance so as to 
prevent spirits from invading a person (Meyer 1998). People asserted that there was a need to actively close themselves to prevent intrusion of their basically permeable selves, for instance by using Jesus as a 'hedge'. Moreover, there are many narratives about illicit connections through which a person gets 'spiritual' access to another person so as to extract his/her riches, or to sacrifice him/ her in exchange for money.

I find this awareness of being connected with other people, spirits, and things very intriguing. This grounded sense of relationality (Spies 2009) and personal permeability is part of a different sense of being in the world than that stipulated by modern Western models that emphasize individualism, grounded in the idea of what Charles Taylor called a 'buffered self' (2008). While some connections are to be blocked, others are to be actively pursued and exploited. This has been one of the reasons for Ewe people's strong interest in the spiritual powers they sought to access via Western missionaries. Throughout my research I have been fascinated by people's preparedness to accommodate new and foreign powers, ideas, and practices, a finding that not only complicates a view of Africans as mere passive victims of missionization and colonization, but one that is also at odds with conventional representations of Africa as 'traditional' in the sense of fixed/conservative and as consisting of ethnic groups imagined as ideally pure and authentic. Tradition itself may rather be the ability to recreate and incorporate, as the mediation of 'tradition' through images from Hollywood in video movies (Meyer 2015, chapter 7) or recent instances of traditional priests presenting themselves as experts in voodoo and magic via Facebook and other social media poignantly show (Grossi 2017).

Stressing the strong awareness of relationality - for better and for worsethat underpins African ways of being in the world and doing religion (Bongbma 20o1) does not deny that Africans engage in exclusivist identity politics, privileging authochtons above newcomers who have less rights to a particular area, or call on tradition and heritage to fix a particular identity (Geschiere 2009). As a scholar who studies religion from a historical and anthropological angle, it is not my aim to make ethical-philosophical statements that seek to define Africa in essential terms. This would resuscitate culturalized views of Africans as Europeans' eternal Others and evoke longstanding stereotypes (Geschiere 2021). My interest in ethical-philosophical reflexions by scholars from Africa who spotlight a sense of incompleteness and openness as a central attitude towards the world (e.g., Nyamnjoh 2017; Mbembe 2016) is due to the fact that these reflections are very close to empirical realities that I encounter in my research on the ground, and yet find difficult to articulate via the conventional vocabularies at hand in religious studies and anthropology. Their reflections offer a conceptual entry point for studying religion from Africa. 
My research findings echo certain aspects of the attitude Mbembe famously coined as Afropolitanism: 'a stylistics and a politics, an aesthetics and a certain poetics of the world. It is a manner of being in the world which refuses, on principle, any form of victim identity — which does not mean that it is not conscious of the injustices and the violence which the law of the world inflicted on this continent and its people' (2021, 212). As an ethos of relating to the world, Afropolitanism acknowledges hybridity and relationality rather than insisting on a bounded purity and originality that, as noted, has underpinned Western Christian epistemologies of writing about Africa. It is an ethos taken by people located in between worlds (see also Ott 2017), directed by colonialism to set themselves in relation to a European centre as Other, and yet able to engage 'in a slow and sometimes incoherent dance with forms and signs which we have not been able to choose freely', to invoke Mbembe once again. Of course, I am aware that Afropolitanism is subject to heavy debate among African intellectuals and artists (Coetzee 2017), especially since it questions the ground for race and nation as binding and exclusive concepts for pan-African identities (Balakrishnan 2018; see also Appiah 1992). My point is not to celebrate Afropolitanism as the 'right' attitude, but to acknowledge that the dispositions to which it refers are alive on the ground. Religion, studied in and from Africa, is very much about accommodating Otherness (see also Kramer 1993)-in Ghana this means powerful Islamic spirits from the north, the Christian God, Jesus, Mami Water - and searching for new technologies to access such powers, including possession as well as the use of social media for spiritual purposes. This makes the study of religion from Africa a prime resource for grasping alternative politics and aesthetics of religious worldmaking.

So when studied from Africa, religion may well look otherwise than conventional European ideas suggest. Other attitudes and practices than those one would normally expect when dealing with religion come into the picture. Materiality and relationality are important dimensions of religion that are not confined to Africa, but are relevant to the study of religion at large. There is certainly more to be detected so as to broaden what we take religion to be. Once the givenness of religion in Africa is questioned, alternative possibilities for research emerge.

Studying religion from Africa is even more important at a time in which many Africans come to Europe as refugees and migrants. In fact, European metropoles may well be described as the new frontier zones in which religious and 
other differences are negotiated (Meyer 2018). While people hailing from Africa know a good deal about the longstanding entanglements between Africa and Europe, in Europe many people have no clue about them. For the broader public the colonial history is neglected or simply forgotten, and it is barely realized that Europe too is in a postcolonial phase. Taking seriously the effects of historical entanglements on the here and now is the sine qua non for understanding and intervening in the world, as Macamo and Mbembe convincingly argue. In my view scholarship on Africa has phenomenal resources to help unpack these entanglements and connections, and to spotlight traces of the colonial past and remnants of coloniality in Europe. One important and intriguing possibility to push this further is to study the trajectories of objects assembled in colonial times in Africa, as well as in other zones of colonial outreach. Such an endeavour speaks to the current concern of ethnological museums to critically rethink their collections and the provenance of their objects; the urgency of doing so is enhanced in the light of calls for their repatriation and restitution to Africa (Sarr and Savoy 2018). Many of these objects have been classified as religious, and exactly for this reason expertise in the study of religion in - and from-Africa is indispensable to understanding their trajectory across the entangled African-European colonial history and its aftermath. This certainly forms an exciting future research field.

For example, I have just embarked on a research project that focuses on a collection of legba-figures (so-called fetishes) and dzokawo (a collection of charms), assembled more than 100 years ago by missionaries of the Norddeutsche Mission among the Ewe and given to the Übersee-Museum (formerly the Städtisches Museum für Natur-, Völker- und Handelskunde). These objects are particularly interesting since many of them were discarded by their original owners and users who converted to Christianity and were expected to get rid of them. The objects were packed and classified as 'fetishes' and 'charms', and started a new life in the museum as ethnographic exponents of Ewe religion that the missionaries regarded as 'idolatrous' or 'fetishist' and scholars as primitive. The objects underwent reclassification because the term 'fetish' came to be considered embarrassing, and most of them are tucked away in the underground depot or in the Schaumagazin, an archive accessible to the public. These collections are fascinating instances of religion from Africa in Europe-literally.

Analysing their trajectory and the change of meaning and valuation they underwent also requires a critical analysis that takes into account how their original use and value for the Ewe was overlaid by European classifications as 'fetishes' and 'charms', and later on simple ethnographic objects to be kept and protected by the museum. These objects invite us not only to discover more 
about their original use and function as well as the powers vested in them, but also to explore their conversion into 'idols', 'fetishes' and 'charms', through which they became specimens of hierarchically ordered types and stages of religion. During a visit to Ghana in January 2020, I presented to Ewe priest Christopher Voncujovi a set of pictures of legba-figures and dzokawo that I had received from the curator Silke Seybold. ${ }^{10}$ In his shrine legba-figures are alive and kicking, and he was highly surprised that these objects were kept in a museum in Bremen. He very much wondered about the circumstances under which they had been collected. He also thought that these objects still contained power, and probably were hungry since they had not been fed for more than 100 years. They might want to come back, but since many Christians, certainly Pentecostals, view such objects as dangerous 'fetishes' or 'idols' - the two terms are used interchangeably-from which they are to stay aloof, he could not imagine the Ghanaian government asking for restitution. It remains to be seen how a close study, not simply of the objects as such but of the stations of their trajectory, will allow a critical study of religion from Africa that will prompt us to rethink the notions of 'bad objecthood' (Mitchell 2005) such as 'fetish', 'idol', and 'charm'. These are matters from the past to be remembered in the here and now (Fabian 1996). As this example shows, European museums contain a great deal of such 'colonial objects' that are a 'pressing matter' (Modest 2017). These objects enshrine colonial entanglements and ask to be unpacked through a collaborative effort that involves African and European scholars, curators, and priests.

So what is religion in Africa? I hope to have conveyed that this is not a straightforward question, and that there is no simple answer. The question itself is already embedded in a historical frame that exceeds Africa: religion in Africa must be traced to the connection with Europe, through which religion was introduced as a concept in the first place. Rather than discarding the concept as foreign, I argued that it is more productive to investigate what religion might have been in Africa and could be in the future by focusing on the repercussions of the introduction of the concept and related terms into Africa. Through inadequate and imperfect translations, new possibilities for conceptualizing religion arise that exceed the problematic Western, Christian bias from which it is usually studied. In this sense we could say, albeit provisionally, that in and from Africa religion appears as down to earth, open to the foreign, and grounded in relational webs - and thus as a modality of being in and relating to power in 
the world that cannot be contained by concepts such as belief and (church) community. Of course, scholars studying religion in Africa have long known this, and their scholarship offers an important resource in explicitly rethinking what religion in Africa is. Clearly, religion in Africa cannot be contained by, and at the same time challenges, the 'epistemological ethnocentrism' that has long informed its study. It is something else than has long been assumed, and what it might be can only be answered through the joint and collaborative efforts of African and Western scholars.

\section{Acknowledgement}

This essay is based on a set of earlier lectures ('Studying Religion in and from Africa', University of Bayreuth 6 November 2017, Leeds University 25 January 2018; 'How Economy Matters. Materiality, Relationality and Exchange in the Study of Religion from Africa', UNISA 4 September 2019; 'What is Religion in Africa?, African Studies Centre Leiden 30 January 2020. For a recording of the lecture see: https://www.youtube.com/watch?v=oZGo4i_CDVU\&list=PL3jTXk JkroYTwixZixQPruobQljLZvHsu\&index=3\&t=5s). It was also discussed in the 'Thinkers and Theorizing from the South' colloquium at the Leibniz-Zentrum Moderner Orient on 27 November 2020. I am thankful for the stimulating questions and comments I received from the listeners. Special thanks to Judith Bachmann, Peter Geschiere, Ulrike Freitag, Angelantonio Grossi, Marloes Janson, Adriaan van Klinken, Erik Meinema, Dieter Neubert, Eva Spies, Johan Strijdom, Rijk van Dijk, and one anonymous reviewer for great suggestions and encouragement. I am most grateful to Benedikt Pontzen for offering a close, critical reading and very useful suggestions. Of course, all shortcomings are mine. The research on which this essay is based was made possible by the Spinoza-prize of the Netherlands Foundation for Scientific Research (NWO), the Academy professor prize of the Royal Netherlands Academy of Arts and Sciences (KNAW), and the Department of Philosophy and Religious Studies at Utrecht University.

\section{References}

Adjei, Sela Kodjo. 2019. Philosophy of Art in Ewe Vodu Religion. Accra: University of Ghana.

Adogame, Afeosemime U. 2013. The African Christian Diaspora: New Currents and Emerging Trends in World Christianity. London: Bloomsbury Academic. 
Appiah, Anthony. 1992. In My Father's House: Africa in the Philosophy of Culture. New York: Oxford University Press.

Asad, Talal. 1986. 'The Concept of Cultural Translation in British Social Anthropology'. In James Clifford and George E. Marcus (eds.), Writing Culture: The Poetics and Politics of Ethnography. Berkeley: University of California Press, 141-164.

Asad, Talal. 1993. Genealogies of Religion:Discipline and Reasons of Power in Christianity and Islam. Baltimore, MD: Johns Hopkins University Press.

Balakrishnan, Sarah. 2018. 'Afropolitanism and the End of Black Nationalism.' In Gerard Delanty (ed.), Routledge International Handbook of Cosmopolitanism Studies. London: Routledge, $375^{-385}$.

Balkenhol, Markus, Ernst van den Hemel, and Irene Stengs (eds.). 2020. The Secular Sacred: Emotions of Belonging and the Perils of Nation and Religion. New York: Palgrave Macmillan.

Barber, Karen. 1981. 'How Man Makes God in West Africa:Yoruba Attitudes towards the Orisa'. Africa 51.3, 724-745.

P'Bitek, Okot. 2011[1971]. Decolonizing African Religion: A Short History of African Religions in Western Scholarship. New York: Diasporic Africa Press.

Bongmba, Elias Kifon. 2001. African Witchcraft and Otherness: A Philosophical and Theological Critique of Intersubjective Relations. New York: State University of New York Press.

Bräunlein, Peter J. 2016. 'Thinking Religion Through Things: Reflections on the Material Turn in the Scientific Study of Religion|s." Method \& Theory in the Study of Religion 28.4-5, 365-399.

Brenner, Louis. 1989. "Religious" Discourses in and about Africa'. In Karin Barber and P.F. de Moraes Farias (eds.), Discourse and Its Disguises. Birmingham: Centre of West African Studies, 87-105.

Chakrabarty, Dipesh. 2001. Provincializing Europe: Postcolonial Thought and Historical Difference. Princeton, NJ: Princeton University Press.

Chidester, David. 1996. Savage Systems: Colonialism and Comparative Religion in Southern Africa. Charlottesville: University Press of Virginia.

Chidester, David. 2014. Empire of Religion: Imperialism and Comparative Religion. Chicago, IL: University of Chicago Press.

Chitando, E. 1997. 'A Curse of the Western Heritage? Imagining Religion in an African Context'. Journal for the Study of Religion 10.2, 75-98.

Coetzee, Carli (ed.). 2019. Afropolitanism: Reboot. London: Routledge.

Comaroff, Jean, and John Comaroff. 2011. Theory from the South: How Euro-America is Evolving Toward Africa. Stellenbosch: STIAs.

De Witte, Marleen. 2004. 'Africania's Dilemma: Reframing African Authenticity in a Christian Public Sphere'. Etnofoor 17.1/2, 133-155.

De Witte, Marleen. 2008. 'Spirit Media: Charismatics, Traditionalists, and Mediation Practices in Ghana'. PhD thesis, University of Amsterdam. 
Engelke, Matthew. 2015. 'Secular Shadows: African, Immanent, Post-Colonial'. Critical Research on Religion 3.1, 86-100.

Evans-Pritchard, Edward. 1956. Nuer Religion. Oxford: Clarendon Press.

Fabian, Johannes. 1983. Time and the Other: How Anthropology Makes Its Object. New York: Columbia University Press.

Fabian, Johannes. 1996. Remembering the Present: Painting and Popular History in Zaire. Narrative and Paintings by Tshibumba Kanda Matulu. Berkeley: University of California Press.

Fabian, Johannes. 2007. Memory against Culture: Arguments and Reminders. Durham, NC: Duke University Press.

Geschiere, Peter. 1997. The Modernity of Witchcraft: Politics and the Occult in Postcolonial Africa. Charlottesville: University Press of Virginia.

Geschiere, Peter. 2009. The Perils of Belonging Autochthony, Citizenship, and Exclusion in Africa and Europe. Chicago, IL: University of Chicago Press.

Geschiere, Peter. 2021. 'Dazzled by New Media-Mbembe, Tonda and the Mystic Virtual'. African Studies Review 64.1, 71-85.

Greene, Sandra E. 1996. 'Religion, History and the Supreme Gods of Africa: A Contribution to the Debate'. Journal of Religion in Africa 26.2, 122-138.

Grossi, Angelantonio. 2017. 'Vodu and Social Media in Ghana'. https://religiousmatters .nl/vodu-and-social-media-in-ghana/.

Hanks, William F., and Carlo Severi. 2014. 'Translating Worlds: The Epistemological Space of Translation'. HAU: Journal of Ethnographic Theory 4.2, 1-16.

Horton, Robin. 1975a. 'On the Rationality of Conversion: Part I'. Africa 45.3, 219-235.

Horton, Robin. 1975b. 'On the Rationality of Conversion: Part II'. Africa 45.4, 373-399.

Horton, Robin. 1984. 'Judaeo-Christian Spectacles: Boon or Bane to the Study of African Religions?' Cahiers d'etudes africaines 24.96, 391-436.

Ikenga-Metuh, Emefie. 1982. 'Religious Concepts in West African Cosmogonies. A Problem of Interpretation'. Journal of Religion in Africa 13.1, 11-24.

Janson, Marloes. 2021. Crossing Religious Boundaries. Islam, Christianity, and 'Yoruba Religion' in Lagos, Nigeria. Cambridge: Cambridge University Press.

Janson, Marloes, and Birgit Meyer. 2016. 'Introduction: Towards A Framework for the Study of Christian-Muslim Encounters in Africa'. Africa 86.4, 615-619.

Klinken, Adriaan van. 2020. 'Studying Religion in the Pluriversity: Decolonial Perspectives'. Religion 50.1, 148-155.

Kramer, Fritz W. 1993. The Red Fez: Art and Spirit Possession in Africa. London: Verso.

Lambek, Michael. 2008. 'Provincializing God? Provocations from an Anthropology of Religion'. In Hent de Vries (ed.), Religion beyond a Concept. New York: Fordham University Press, 120-138, 856-857.

Latour, Bruno. 2010. On the Modern Cult of the Factish Gods. Durham, NC: Duke University Press. 
Luhrmann, Tanya M. 2012. 'A Hyperreal God and Modern Belief: Toward an Anthropological Theory of Mind'. Current Anthropology 53.4, 371-395.

Macamo, Elísio. 1998. Was ist Afrika? Zur Geschichte und Kultursoziologie eines modernen Konstrukts. Berlin: Duncker \& Humblot.

Macamo, Elísio. 2018. 'Urbane scholarship: Studying Africa, Understanding the World'. Africa 88.1, 1-10.

Mbembe, Achille. 2007. 'Afropolitanism'. In Simon Njami (ed.), Africa Remix: Contemporary Art of a Continent. Johannesburg: Jacana Media, 26-29.

Mbembe, Achille. 2017. Kritik der schwarzen Vernunft. Frankfurt: Suhrkamp.

Mbembe, Achille. 2021. Out of the Dark Night: Essays on Decolonization. New York: Columbia University Press.

Mbiti, John S. 1969. African Religions and Philosophy. Nairobi: Heinemann.

Meinema, Erik. 2021. 'Regulating Religious Co-Existence: The Intricacies of "Interfaith" Cooperation in Coastal Kenya'. PhD thesis, Utrecht University.

Meyer, Birgit. 1997. 'Christian Mind and Worldly Matters: Religion and Materiality in Nineteenth-Century Gold Coast'. Journal of Material Culture 2.3, 311-337.

Meyer, Birgit. 1998. "Make a Complete Break with the Past": Memory and Post-Colonial Modernity in Ghanaian Pentecostalist Discourse'. Journal of Religion in Africa 28.3, 316-349.

Meyer, Birgit. 1999. Translating the Devil: Religion and Modernity among the Ewe in Ghana. Edinburgh: Edinburgh University Press.

Meyer, Birgit. 2012. 'Mediation and the Genesis of Presence: Towards a Material Approach to Religion'. Inaugural lecture, Utrecht University.

Meyer, Birgit. 2015. Sensational Movies: Video, Vision, and Christianity in Ghana. Oakland, CA: University of California Press.

Meyer, Birgit. 2018. 'Frontier Zones and the Study of Religion'. Journal for the Study of Religion $31.2,57-78$.

Meyer, Birgit. 2019. 'Recycling the Christian Past. The Heritagization of Christianity and National Identity in the Netherlands'. In Rosemarie Buikema, Antoine Buyse, and Antonius C.G.M. Robben (eds.), Cultures, Citizenship and Human Rights. London: Routledge, 64-88.

Meyer, Birgit. 2020a. 'Remapping Our Mindset: Towards a Transregional and Pluralistic Outlook'. Religion 50.1, 113-121.

Meyer, Birgit. 2020b. 'Religion as Mediation'. Entangled Religions 11.3 (online, https:// er.ceres.rub.de/index.php/ER/article/view/8444).

Mignolo, Walter. 2013. 'On Pluriversality'. http://waltermignolo.com/on-pluriversality/. Mitchell, W.J. Thomas. 2005. What Do Pictures Want?: The Lives and Loves of Images. Chicago, IL: University of Chicago Press.

Modest, Wayne. 2017. 'Pressing Matter: Reckoning with Colonial Heritage'. Inaugural lecture, Vrije Universiteit Amsterdam. 
Mudimbe, V.Y. 1988. Invention of Africa: Gnosis, Philosophy, and the Order of Knowledge. Bloomington: Indiana University Press.

Nieber, Hanna. 2020. 'Drinking the Written Qur'an Healing with Kombe in Zanzibar Town'. PhD thesis, Utrecht University.

Nolte, Insa, Olukoya Ogen, and Rebecca Jones (eds.). 2017. Beyond Religious Tolerance: Encounters between Muslims, Christians and Traditionalists in an African Town. Rochester, NY: James Currey /Boydell and Brewer.

Nyamnjoh, Francis B. 2017. 'Incompleteness: Frontier Africa and the Currency of Conviviality'. Journal of Asian and African Studies Journal of Asian and African Studies 52.3, 253-270.

Nye, Malory. 2019. 'Decolonizing the Study of Religion'. Open Library of Humanities 5.1, https://doi.org/10.16995/olh.421.

Olabimtan, Kehinde. 2003. “Is Africa Incurably Religious?” A Response to Jan Platvoet and Henk van Rinsum'. Exchange 32.4, 322-339.

Ott, Michaela. 2017. "Afropolitanism” and an Example of Contemporary Aesthetics'. In Dan-Eugen Ratiu and Connel Vaughan (eds.), Proceedings of the European Society for Aesthetics, 308-411. http://proceedings.eurosa.org.

Parrinder, Geoffrey. 1969. Religion in Africa. Baltimore, MD: Penguin Books.

Pew Research Center and Pew-Templeton Global Religious Futures Project. 2015. The Future of World Religions: Population Growth Projections, 2010-2050: Why Muslims Are Rising Fastest and the Unaffiliated Are Shrinking as a Share of the World's Population. http://www.globalreligiousfutures.org.

Platvoet, Jan, and Henk van Rinsum. 2003. 'Is Africa Incurably Religious?' Exchange $32.2,123^{-153 .}$

Platvoet, Jan. 2004. 'Does God Have a Body?: On the Materiality of Akan Spirituality'. In Christoph Kleine, Monika Schrimpf, and Katja Triplett (eds.), Unterwegs: Neue Pfade in der Religionswissenschaft. Festschrift für Michael Pye zum 65. Geburtstag. New Paths in the Study of Religions. Festschrift in Honour of Michael Pye on his 65th Birthday. München: Biblion Verlag, 175-195.

Pontzen, Benedikt. 2019. 'How One Religion Sees Another: Islamic Framings of "African Traditional Religion" in Asante (Ghana)'. Paper presented at ECAS 2019, Edinburgh University.

Richter, Roxane, Thomas Flowers, and Elias Kifon Bongmba. 2017. Witchcraft as a Social Diagnosis: Traditional Ghanaian Beliefs and Global Health. Lanham, MD: Lexington Books.

Sarr, Felwine, and Bénédicte Savoy. 2018. The Restitution of African Cultural Heritage: TowardaNewRelationalEthics.http://restitutionreport2018.com/sarr_savoy_en.pdf. Shaw, Rosalind. 199o. 'The Invention of "African Traditional Religion". Religion 20, 339-353. 
Spies, Eva. 2019. 'Being in Relation: A Critical Appraisal of Religious Diversity and Mission Encounter in Madagascar'. Journal of Africana Religions 7, 62-83.

Spieth, Jacob. 1911. Die Religion Der Eweer in Süd-Togo. Leipzig: Dietersche Verlagsbuchhandlung.

Taylor, Charles. 2007. A Secular Age. Cambridge: Belknap.

Taylor, Charles. 2008. 'Buffered and Porous Selves', ssRC-Blog The Immanent Frame, 2.9.2008: https://tif.ssrc.org/2008/o9/o2/buffered-and-porous-selves/.

Warneck, Gustav. 2015[1897]. Evangelische Missionslehre. Ein missionstheoretischer Versuch. Mit einer Einführung von Prof. Dr. Thomas Schirrmacher. Band 1. Bonn: Verlag für Kultur und Wissenschaft.

Wijsen, Frans. 2017. 'Are Africans Incurably Religious?' Exchange 46.4, 370-397.

Wiredu, Kwasi. 2011. 'Introduction: Decolonizing African Philosophy and Religion'. In Okot P'Bitek (ed.), Decolonizing African Religions. A Short History of African Religions in Western Scholarship. New York: Diasporic Africa Press, xi-xxxvii.

Zobel, Clemens. 2011. 'On the Pre-Conditions of Beginning a Discourse on Matters in Africa." Outras Áfricas 1, https://doi.org/10.400o/eces.677.

\section{Notes}

1 See Elisio Macamo's (1998) book Was ist Afrika? Zur Geschichte und Kultursoziologie eines modernen Konstrukts (What is Africa? About the history and cultural sociology of a modern construct) in which he unpacks, from the angle of sociology of knowledge in the footsteps of Karl Mannheim, how an idea of Africa as antimodern paradoxically emerged out of the modern genesis of the concept of Africa that African philosophers have deployed since the late nineteenth century in response to the experiences of the slave trade and colonization.

2 For an extensive discussion of Chidester's notion of the frontier zone and his overall approach see Meyer 2018.

3 Translation depended on intense collaboration between Ewe mission workers and the missionaries. Without the former the latter would not have been able to convey their ideas to the Ewe, let alone to translate back. However, in this translation the two languages were not equal. Ewe terms were brought into a German-Christian mould. Exactly for this reason, it is important to study translation as embedded in power relations. Translation is about making and breaking worlds. In my work (1999), I have attempted to follow the practice of missionary translation so as to open up other possibilities for meaning that emerge from an Ewe point of view.

4 Matters become even more complicated when the concept of din (Arabic) or dini (Swahili), which is usually translated as religion, is taken into account. On the one hand, Islamization involved the spread of this concept and its translation into indigenous ideas, and on the other hand din/dini were employed as equivalent to 'religion' in the European sense. See Nieber 2020 for unpacking the complexities of the dini/religion relation in Zanzibar.

5 Over and over again, when trying to convey research findings to a mainstream German or Dutch public, I encounter certain prejudices and stereotypes according to which Africa is understood to be far away, a continent in which irrational beliefs and superstitions are 'still' thriving. Such ideas are also projected on African migrants and refugees in Europe. 
6 Launched as a somewhat polemical critique of Christian appraisals of African religiosity, especially in the context of intercultural theology, the authors draw a strong line between a religionist and a methodologically agnostic view (the prevailing stance in religious studies). They were strongly criticized by Olabitman (2003), who argued that they failed to notice the shift toward postmodernism that, in questioning the distinction between belief and science, allowed for adopting a religionist stance as a scholar. Frans Wijsen (2017) offers a thorough analysis of the debate grounded in discourse analysis. While I agree with the basic argument made by Platvoet and van Rinsum, my concern is not to criticize religionism but to problematize how a Western notion of religion that even extends to the notion of secularity shapes scholarly epistemologies in the study of religion in Africa.

7 While the question of whether the term 'religion' could be equivalent to din or dini (Arabic and Swahili for 'religion', see Nieber 2020) has been subject to debate among Muslims, from the perspective of the state Islam was framed as a religion comparable to Christianity, and hence to be subject to the same religion (Meinema 2021). How 'religion' and 'din' differ or overlap forms an important issue for future comparative research. My thanks to Benedikt Pontzen for pointing this out to me.

8 While my thinking resonates with Walter Mignolo's idea of the pluriverse as 'a world entangled through and by the colonial matrix of power' and this 'as a way of thinking und understanding that dwells in the entanglement, in the borders' to a great extent, I still think that it is worthwhile and important for scholars to strive to develop a metalanguage that allows us to compare and speak across. That the 'universalization of universality in the West was part of its imperial project' (2013, waltermignolo.com/on-pluriversality) is in my view all the more reason to strive toward an alternative universalism that accommodates differences in a nonhierarchical manner. This is what I am trying to contribute to with this essay.

9 Post-Enlightenment Protestant ideas about and stances toward the world became part of the study of religion in secular form, and the ensuing mentalistic bias had a stronger influence on concepts and approaches than Catholicism. The extent to which Catholic missionary ideas informed the study of religion in Africa is still to be unpacked.

10 I was introduced to Christopher Voncujovi by my PhD student Angelantonio Grossi, who conducts research on traditional priests and their use of social media. 